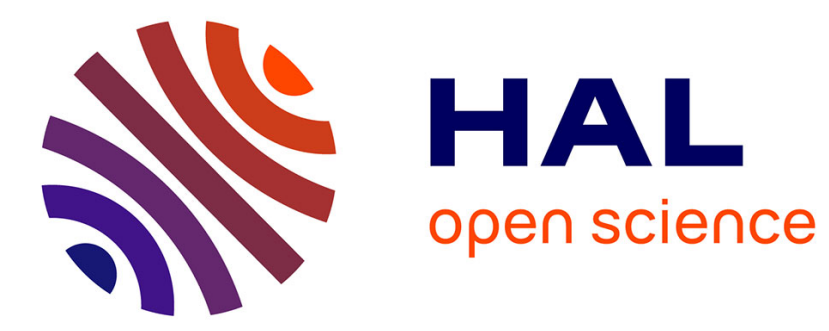

\title{
Evaluation of the Effect of Chemical or Enzymatic Synthesis Methods on Biodegradability of Polyesters
}

Laurent Goujard, Pierre-Jean Roumanet, Bruno Barea, Yann Raoul, Fabio

Ziarelli, Jean Le Petit, Nathalie Jarroux, Elisée Ferré, Philippe Guégan

\section{- To cite this version:}

Laurent Goujard, Pierre-Jean Roumanet, Bruno Barea, Yann Raoul, Fabio Ziarelli, et al.. Evaluation of the Effect of Chemical or Enzymatic Synthesis Methods on Biodegradability of Polyesters. Journal of Polymers and the Environment, 2016, 24 (1), pp.64-71. 10.1007/s10924-015-0742-7 . hal-01285524

\section{HAL Id: hal-01285524 \\ https://hal.sorbonne-universite.fr/hal-01285524}

Submitted on 9 Mar 2016

HAL is a multi-disciplinary open access archive for the deposit and dissemination of scientific research documents, whether they are published or not. The documents may come from teaching and research institutions in France or abroad, or from public or private research centers.
L'archive ouverte pluridisciplinaire HAL, est destinée au dépôt et à la diffusion de documents scientifiques de niveau recherche, publiés ou non, émanant des établissements d'enseignement et de recherche français ou étrangers, des laboratoires publics ou privés. 
1 Evaluation of the effect of chemical or enzymatic synthesis methods on biodegradability

2 of polyesters

3 Goujard Laurent, Roumanet Pierre-Jean, Barea Bruno, Raoul Yann, Ziarelli Fabio, Le Petit

4 Jean, J Jarroux Nathalie, 'Ferré Elisée, Guégan Philippe*

$5 *$ Corresponding author

6

\section{Abstract}

8 This work compares the biodegradability of polyesters produced by an esterification reaction

9 between glycerol and oleic di-acid (D 18:1) issued from green chemical pathways, via either classical thermo-chemical methods, or an enzymatic method using the immobilized lipase of Candida antartica B (Novozym 435). An elastomeric polymer synthesized by enzymatic catalysis is more biodegradable than an elastomeric thermo-chemical polyester synthesized by

Philippe Guégan, Université Pierre et Marie Curie : philippe.guegan@upmc.fr

J-P. Roumanet, N. Jarroux University of Evry Val d'Essone, Team of Material Polymers of Interfaces, LAMB, CNRS UMR 8587, Boulevard F. Mitterand, 91025 Evry, France

B. Barea SUPAGRO/INRA - UMRIATE 1208, CIRAD-Lipotechnie, Bât. 33, 2 Place Viala, 34060 Montpellier cedex 1, France

Y. Raoul ONIDOL, 11 rue Marceau CS 60003, 75378 Paris cedex 08, France

F. Ziarelli Université Aix-Marseille, CNRS-FR1739, Faculté de Saint-Jérôme, Case 512, 13397 Marseille cedex 20, France J. Le Petit, E. Ferré, Aix-Marseille University, IMBE, UMR CNRS - IRD 7263, Faculty of Saint-Jérôme, Case 452, 13397 Marseille cedex 20, France

Ph. Guégan Sorbonne Universités, UPMC University Paris, IPCM, Chimie des Polymères, Paris, France -CNRS, IPCM, Chimie des Polymères, Paris, France 
a standard chemical procedure. This difference lies in percentage of the dendritic motifs, in values of the degree of substitution, and certainly in cross-links inducing an hyper-branched structure less accessible to the lipolytic enzymes in a waste treatment plant. However, when the elastomeric polymer synthesized by enzymatic catalysis is processed at high temperature as required for certain industrial applications, it presents an identical rate of biodegradation than the chemical polyester. The advantages of the thermo-chemical methods are greater speed and lower cost. Enzymatic synthesis appears be suited to producing polyesters, devoid of metallic catalysts, which must be used without processing at high temperature to keep a high biodegradability.

Keywords : chemical polyesters, enzymatic polyesters, biodegradability

\section{Introduction}

Production of synthetic polymers from petroleum compounds dates back to the beginning of the $20^{\text {th }}$ century and played a major role in the economic development of industrialized countries. Since 1970, however, it has been recognized that these polymers are resistant to degradation by microorganisms, once used, create problems of pollution and disposal both in the natural medium and in waste treatment plants. When designing new materials, therefore, efforts have been made to provide for not only their texture, their mechanical resistance or their moistness, but also for their biodegradability [1], while ensuring that this does not occur during use.

Taking polyethylene as an example, there is practically no diffusion of water and oxygen in the polymer. Only the surface, with a reduced number of free chains, is open to attack by extracellular enzymatic reactions. Addition of pro-oxidant derivatives (Manganese and Cobalt salts) leads to release free radicals which, exposed to light, allow the formation of 
hydroperoxides and then lead to the cleavage of the polyethylene $[2,3]$. These conditions $[4]$ reduce the molecular weight, but only $20 \%$ of fragments with $\mathrm{Mw}<1000 \mathrm{~g} / \mathrm{mole}$ can be mineralized by microorganisms. These fragments, which are hydrocarbons, follow various known metabolic pathways for alkanes with terminal, di-terminal or sub-terminal oxidation [5]. Thus, such polymers are not biodegradable according to norm NE 13432 for compostability. The long-term effects of accumulation of oligo- and poly-olefins in soils are not yet known [6].

Other biodegradable polymers can be synthesized using various natural resources and processes [7]. Examples include agro-polymers produced from vegetal biomasses [8], polymers produced from microbial metabolism such as poly-hydroxyalkanoates [9] and polymers synthesized from monomers produced by bacterial fermentations, i.e. poly(lactic acid) $[10,11]$ which is the principal polyester based on renewable raw material commercialized at industrial scale [12].

There are two ways of catalysing the poly-condensation of poly-acids and poly-ols to obtain polyesters: using either organo-metallic compounds [13] or enzymes [11]. The chemical method is efficacious and rapid, allowing the synthesis of many important polymers. Yet the various organo-metallic catalysers $[14,15]$ in these reactions cannot be fully eliminated after synthesis with the ensuing risk that they will confer toxicity to the polymers, and accumulation in soils. Chemical synthesis of polyesters requires high temperatures, sometimes exceeding $200^{\circ} \mathrm{C}$. Such temperatures can lead to secondary reactions liable to modify the stoechiometry of the polymerization through, for example, dehydration of diols or degradation of glycerol into acroleine. However, polymerization using chemical catalysis allows for the production polymers on a large scale and in a short reaction time, with limited purification steps afterwards. 
The enzymatic synthesis of biodegradable polymers from renewable resources has attracted great interest. Thus, lipases which are enzymes used in many biotechnological fields $[16,17]$ can hydrolyse polyesters or catalyse the inverse reaction, the esterification. Balance between hydrolyse and esterification reactions is controlled by the quantity of water in the reacting medium. For the esterification reactions, the quantity of water allowing the optimal activity corresponds to the water molecules hardly bound to protein structure which are necessary to maintain their enzymatic conformation.

Whatever the mode of polymer synthesis, it is necessary to distinguish degradation from biodegradation. In the first case, the polymer undergoes an irreversible alteration of its chemical structure, leading to loss of its properties and functions. These alterations can be caused by abiotic phenomena such as mechanical hindrances, light, heat and hydrolysis or oxidation reactions [18]. Biodegradation is a degradation catalysed by microorganisms which can divide polymers into monomers. These monomers are then either mineralized into $\mathrm{H}_{2} \mathrm{O}$ and $\mathrm{CO}_{2}$ with energy production, or transformed into biomass and secondary metabolites [19]. Contrary to transformation by abiotic phenomena, catalysis by microorganisms allows organic matter recycling.

Here, we aimed to determine the effect of the mode of polyester synthesis, namely chemical or enzymatic or even a combination of the two methods, on the chemical structure of these polymers, and thus on their biodegradability. In particular, we focused on the effect of the temperature during the thermic phase, used in certain processing, on the biodegradability of polyesters obtained from glycerol and oleic di-acid (D18-1). These two compounds are issued from a green chemical pathway: glycerol is issued from the biodiesel production [20] and the oleic di-acid results of the enzymatic oxidation of the alkyl extremity of the oleic acid by Candida tropicalis [21]. Kulshrestha et al [22], Yang et al [23] and Zhang et al [24] already reported the use of glycerol and oleic di-acid as polymer precursor but only under the 
chemical aspect of the synthesized products. Our study was conducted, either by chemical techniques or by the lipase [25] of Candida antarctica B (Novozym 435) immobilized on a polyacrylic matrix. To measure the biodegradability of polyesters, the lipase of Rhizopus arrhizus was often used [26, 13], but in this work we chose the most common laboratory test based on standardized respirometric techniques resulting in oxygen consumption and $\mathrm{CO}_{2}$ release [27] when microorganisms present, for example, in activated mud or compost or soil, are placed in contact with a polymer.

\section{Experimental}

Synthesis of polyesters

Monomers used: cis 9 octadecen dioic acid (oleic di-acid : D 18:1) was supplied by Cognis (France). It was first purified by solubilisation in dichloromethane to remove insoluble saturated by-products and then recrystallized in petroleum ether to remove soluble monoacids. Its purity was evaluated by GC at $97 \%$. Glycerol was supplied by Acros Organics (purity 99 $\%)$.

Five polymers were synthesized from D 18:1 and glycerol in an equimolecular mixture: 1. a thermal polymer obtained by heating the monomer mixture at $65^{\circ} \mathrm{C}$, the temperature used in enzymatic methods; 2 . monomers mixed by rotary stirring and heated at $160^{\circ} \mathrm{C}$ for $3 \mathrm{~h}$ and at $180^{\circ} \mathrm{C}$ for $1 \mathrm{~h} ; 3$. a polyester synthesized by first heating at $160^{\circ} \mathrm{C}$ under nitrogen flux for $8 \mathrm{~h}$ in a $100 \mathrm{~mL}$ reactor with blade stirring and then dissolving the mixture in dichloromethane, precipitated in cold methanol $\left(-40^{\circ} \mathrm{C}<\mathrm{t}^{\circ}<-30^{\circ} \mathrm{C}\right)$ and recovering it; 4. an enzymatic polymer obtained with Novozym $435(0.1 \%)$ at $65^{\circ} \mathrm{C}$ in a glass reactor $100 \mathrm{~mm}$ high for 6 days; 5. a polyester synthesized by heating at $160^{\circ} \mathrm{C}$ for $4 \mathrm{~h}$ of a pre-polymer obtained by enzymatic catalyse such as for the polymer 4 but stopped at a viscous liquid physical state. 
Polymers 1, 4 and 5 were stirred in a glass reactor with an ARZR1 (Heidolph) motor equipped with a rod supporting a mixing blade $(4.5 \mathrm{~cm}$ diameter). All the reactor were immersed in an oil-bath.

Elementary analysis

Carbon, hydrogen and oxygen atom percentages in polymers were determined with a Thermo Finnigan EA 1112 Elementary Analyser.

\section{Measure of the $\mathrm{M}_{\mathrm{W}}$ and $\mathrm{Mn}$ polymers}

This measure was realized by steric exclusion chromatography with a PLgel $5 \mu \mathrm{m}$ MiniMIXD column $(250 \times 4.6 \mathrm{~mm})$. This column was protected by a PLgel $5 \mu \mathrm{m}$ MiniMIX-D Guard pre-column $(50$ x $4.6 \mathrm{~mm})$. Both columns were provided by Polymer Lab. They were supplied continuously with a gas-free tetrahydrofurane (THF) via a Waters 515 pump with a $0.3 \mathrm{~mL}$. $\min ^{-1}$ delivery. Prior to analysis, solutions were filtered through $0.45 \mu \mathrm{m}$ Millex-HV filters from Polymer Lab. Twenty $\mu \mathrm{L}$ at $3 \mathrm{~g} \mathrm{~L}^{-1}$ were injected at room temperature. This chromatographic chain was equipped both with a Waters 410 refractometer (thermostated at $35^{\circ} \mathrm{C}$ ) and a UV Waters 2487 detector. Data acquisition was realized with OmniSEC by Viscotek.

\section{Nuclear Magnetic Resonance}

The insoluble samples were analyzed by ${ }^{13} \mathrm{C}$ High Resolution Magic Angle Spinning (HRMAS) technique on a Bruker Avance $400 \mathrm{MHz}$ spectrometer operating at a ${ }^{13} \mathrm{C}$ resonance frequency of $106 \mathrm{MHz}$ and using a HRMAS Bruker double-bearing probe. About 3-4 mg of sample were swollen with $50 \mu \mathrm{L}$ of $\mathrm{CDCl}_{3}$ in a $4 \mathrm{~mm}$ zirconium dioxide rotor, equipped with Teflon spacers, and spun at $4 \mathrm{kHz}$. The soluble sample was analyzed by ${ }^{13} \mathrm{C}$ Liquid State Bruker Avance $300 \mathrm{MHz}$ spectrometer operating at a ${ }^{13} \mathrm{C}$ resonance frequency of $76 \mathrm{MHz}$ and using a commercial Bruker BBI probe. About $10 \mathrm{mg}$ of sample were solubilized in a mixture 
of $\mathrm{CDCl}_{3}-\mathrm{d} 1(77.1 \mathrm{ppm})$ and DMSO-d6 (39.7 ppm) in a $5 \mathrm{~mm}$ NMR tube. Attributions of carbons of the glycerol units were deduced from Rabiller and Maze [28] and Mazur et al [29]. All experiments were performed at room temperature and the ${ }^{13} \mathrm{C}$ chemical shifts were referenced to tetramethylsilane (TMS).

Respirometric method

Measures of respiratory activities were realized in an Oxytop System WTW apparatus composed of a manometer and a one litre hermetic flask. Biomasses used were from sludge sampled in the waste treatment plant of Brignoles (Var, France). Into the Oxytop flask were introduced the polymer $(0.25 \mathrm{~g})$, mixed with the biomass $(2.5 \mathrm{~g})$ and a flask containing $50 \mathrm{~mL}$ of $0.2 \mathrm{M} \mathrm{NaOH}$. Oxytop flasks were incubated at $20^{\circ} \mathrm{C}$. Quantities of oxygen consumed were calculated from the lowering of pressure measured by the Oxytop manometers according to the perfect gas law. They were expressed as $\mathrm{mg}$ of $\mathrm{O}_{2}$ consumed per $\mathrm{g}$ of biomass.

Quantities of $\mathrm{CO}_{2}$ released were measured by titration with barium hydroxide of $\mathrm{Na}_{2} \mathrm{CO}_{3}$ formed by reaction of $\mathrm{CO}_{2}$ and $\mathrm{NaOH}$. They were expressed as $\mathrm{mg}$ of $\mathrm{CO}_{2}$ released per $\mathrm{g}$ of biomass. Measures of $\mathrm{CO}_{2}$ were realized every seven days when the Oxytop flasks refilled with air and $\mathrm{NaOH}$.

The biodegradability of polyesters 2, 3, 4 and 5 was compared to the biodegradability of commercial polymers single-use cups formed either with a vegetal pulp (polymer 6) or with a poly(lactic acid) commonly called PLA (polymer 7). The cups were pulverized and the powder thus obtained was dispersed into the biomass in the Oxytop Flasks in the proportions cited above for polyesters.

For each polymer tested, an assay was realized without polymer to measure the respiratory activity of the biomass itself. All the assays were realized in triplicate. 


\section{Results and discussion}

168

169

170

171

172

173

174

175

176

177

178

179

180

181

182

183

184

185

186

Effect of synthesis methods on polyester structure

Glyceridic motifs present in polyesters synthesized by esterification of glycerol by D18-1 diacid are presented in figure 1 and the respective ${ }^{13} \mathrm{C}$ Nuclear Magnetic Resonance (NMR) spectrum is shown in figure 2 corresponding to the polymer 2 . Glyceridic motifs were identified, as further indicated in the experimental part, and their proportions were calculated using integrals of signals of methine carbons. The differences observed in the chemical shifts (1 to $1.5 \mathrm{ppm}$ ), compared to the attributions of Kulshrestha et al [22] were principally due to the different mass concentration and the real sample temperature (about $10-15^{\circ} \mathrm{C}$ ) due to sample Magic Angle Spinning at $4 \mathrm{kHz}$.

Figure 1

Figure 2

Whether using chemical, enzymatic or mixed techniques for polyester synthesis, we observed that proportions of the principal different glyceridic motifs (Fig. 1) depended on the experimental conditions during the successive sequences of polymer synthesis (Table 1). In particular, experiment 1 , conducted at $65^{\circ} \mathrm{C}$, shows that when this temperature is used for enzymatic catalysis, weak, but not negligible polymerization, is induced. 
Table 1 shows that, for all the polymers, primary hydroxyls are more esterified than secondary hydroxyls. This high percentage is partly due to monoglyceride formation in sn1 or sn3 positions, the presence of monoglycerides in sn2 position ( $T_{2}$ motif) not being detected.

Migration of acyl groups from the sn2 position towards sn 1 and sn3 positions, and a higher probability of forming 1- or 3- monoglyceride, explain the absence of 2-monoglyceride [30]. When a second esterification is realized on a 1- or 3-monoglyceride, the other external position is preferentially esterified. The highest proportion of esters in sn2 position is present in dendritic motifs (De), indicating that the decrease in the proportion of available primary hydroxyl induces esterification in sn2 position.

Experiments 2, 3 and 4 show differences between chemical and enzymatic catalysis in percentages of both the $T_{1}$ and dendritic motifs and values of the degree of substitution, defined as the mean number of ester bindings by glycerol unit. Degree of substitution increases with temperature in experiments 2 and 3 (2.1). The two polyesters 2 and 3 thus obtained have 32 and $26 \%$ of the dendritic motifs respectively, which means that their hydroxyl functions sn2 are likely to be involved, in similar proportions, in the increase of the degree of substitution. Nevertheless, the difference in their physical state and their $\mathrm{Mn}$ corresponds to different proportions of the other glyceridic motifs. Enzymatic catalysis with Novozym 435 (polymer 4) induces percentages of $\mathrm{L}_{1,3}$ esters (36\%) identical to those observed in polymer 2 obtained by thermal esterification (36\%), but great difference concern the percentages of dendritic, $\mathrm{L}_{1,2}$ and $\mathrm{T}_{1}$ motifs.

For polymer 5, which presents an elastomeric state, the pre-catalysis with Novozym 435, which leads to a viscous liquid ( $\mathrm{MW}=28000 \mathrm{~g} / \mathrm{mole}, \mathrm{Mn}=2830 \mathrm{~g} / \mathrm{mole}$ ), has an effect on the polymer structure. Its structure is closer to that of the polymer 4 than to that of the 
polymer 2. Thus, polymers 2 and 5 differ greatly, particularly in proportion of both $\mathrm{T}_{1}$ and dendritic motifs and in degree of substitution in spite they both undergo a thermal phase.

\section{Biodegradability of the polyesters}

The degradation of these different polyesters by a biomass from urban sludge mud was measured at $20^{\circ} \mathrm{C}$ by the oxygen consumed and the $\mathrm{CO}_{2}$ released, taking into account the endogen respiration of this biomass. It is important to note that all the polymers tested were treated according to the same experimental protocol, i.e. they were not shaken in Oxytop System. This test of biodegradability differs from the test using the lipase of Rhizopus arrhizus $[13,26]$. An urban sludge contains a great number of microorganism species able to synthesise various types of lipases, thus increasing potentialities of ester-binding hydrolyses.

Two commercial polymers (polymers 6 and 7), considered as biodegradable under current legislation, were selected as references to test the methodology used here to study the biodegradability of the polyesters under consideration.

Consumption of $\mathrm{O}_{2}$ and release of $\mathrm{CO}_{2}$ by a biomass from sludge mud placed in contact with polymers 6 and 7 are given in figure 3; only polymer 6 is degraded in the Oxytop System condition, i.e. at $20^{\circ} \mathrm{C}$.

\section{Figure 3}

The high potential of microorganisms to synthesize cellulases and hemicellulases may explain this high biodegradation rate of the polymer 6 formed with a vegetal pulp. No degradation of polymer 7 formed with PLA was observed in the Oxytop System. To eliminate the hypothesis that the processing at high temperature [31] of the PLA cups could lead to a nonbiodegradable structure, a racemic mixture of polylactic acid isomers (white powder) was subjected to the respiratory Oxytop System. Results are identical to those from experiments 
conducted with PLA. The crystallinity of the PLA is certainly [32] an important parameter which can be taken into account. Indeed, crystalline zones are less hydrolysable than amorphous zones. Moreover, enzymes degrade only the surface of the solid substrate, because they cannot penetrate the polymer systems [33]. As already demonstrated by Weir et al $[34,35]$, the increasing of temperature above $50^{\circ} \mathrm{C}$, temperature reached in industrial compost plants $[36,37]$, modifies the crystalline zones turning them into an amorphous structure, more accessible and thus more biodegradable, so meeting the specifications of three international standards: ASTM D5338, ISO1855 and NF14352. However, in a real soil environment and home composting, the temperature usually does not exceed $30^{\circ} \mathrm{C}$. These results corroborate those of Rudnik and Briassoulis [38] who demonstrated by respirometric methods that PLA materials are not degraded at $30^{\circ} \mathrm{C}$. Consequently, the respiratory Oxytop System allows to differentiate the biodegradability, measured at $20^{\circ} \mathrm{C}$, of polymers studied in this work.

Figure 4 shows results of experiments 2, 3, 4 and 5, indicating that polymers obtained from an equimolecular mixture of glycerol and D 18:1 are mineralized whatever the synthesis mode. Yet the polymers 3 and 4 present a biodegradability higher than the polymers 2 and 5 . Thus, $52 \mathrm{mg}$ and $45 \mathrm{mg}$ of $\mathrm{CO}_{2}$ were respectively released for 35 days from polymers 3 and 4 by $1 \mathrm{~g}$ of biomass from sludge mud. In the same conditions, only $10 \mathrm{mg}$ of $\mathrm{CO}_{2}$ were released from the polymers 2 and 5 . For the polymer 4 , it is important to eliminate the hypothesis that the residual Novozym may act in hydrolysis in the degradation system, thus releasing glycerol and D 18:1. There is need to point out, first, that no free glycerol was detected in polymer 4 at the end of its synthesis (results not shown). Second, when polymer 4 was mixed with urban sludge mud, Novozym 435 was at a maximum concentration of $0.01 \%$, versus $0.1 \%$ for its synthesis phase, and the temperature was at $20^{\circ} \mathrm{C}$, whereas the maximum activity of this enzyme occurs between 65 and $80^{\circ} \mathrm{C}[39]$. 
These results seem indicate that the difficulties for microbial lipases to reach and thus to hydrolyse the ester bindings are not only dependent of the dendritic structure of the polymer. Probably, the thermic treatment subjected by the polymers 2 and 5 results in cross-links and thus in a higher branched structure than in the enzymatic polymer. The higher degree of branching between linear chains, as defined by Hölter et al [40], the greater the likelihood that a hyper-branched polyester will have a typical globular dendrimer structure.

The thermic treatment subjected by the polymer 3, limited at a viscous liquid state, was insufficient to create such structures. Its weak $\mathrm{Mw}$ and its viscous state certainly allowed a better accessibility of the esters bindings to the microbial lipases as it was also observed by Umare et al [41] with 1,3-propanediol based polyesters.

Polymers 4 and 5, despite having fairly similar structures and an elastomeric physical state, are not biodegraded at the same rate. It seems that the enzymatic pre-polymerization interferes with the thermal phase by reducing the proportion of dendritic motifs in polymer 5 as compared to polymer 4 , the processing at $160^{\circ} \mathrm{C}$ for $4 \mathrm{~h}$ then leading to cross-links which confer to the polymer 5 the same biodegradability than the polymer 2 .

Based both on the percentage of carbon in each polymer structure and on the rate of $\mathrm{CO}_{2}$ production (Fig. 3 and 4), it is possible to estimate the approximate time required for $1 \mathrm{~g}$ of biomass sampled in a waste treatment plant to transform $100 \mathrm{mg}$ of polyester into $\mathrm{CO}_{2}$. In the Oxytop System, all the organic carbon can be considered to be transformed into $\mathrm{CO}_{2}$, organic carbon transformation into biomass probably being negligible. Indeed, the lack of no renewable elements such as nitrogen and phosphorus induces an energy decoupling. An extrapolation can be made from this result to a waste treatment plant, where there is permanent nitrogen and phosphorus supplies, taking into account that about $50 \%$ of carbon (C) could be transformed into biomass $[42,43]$. In this case, the time required to transform the 
organic carbon into $\mathrm{CO}_{2}$ and biomass in the Oxytop System, must be divided by approximately 2 .

Table 2 shows the approximate time required for mineralization by $1 \mathrm{~g}$ of biomass of $100 \mathrm{mg}$ of polymers $2,3,4,5$ and 6 .

Table 2

The findings of this study indicate that the mode of synthesis of a polymer should be chosen according both to its intended use and to the properties required. Enzymatic synthesis leads to polyesters which are more biodegradable than those obtained by chemical means, while providing an identical elastomeric state (polymers 2 and 4). A weak molecular mass and a viscous state facilitate biodegradation. A thermal phase induces a higher proportion of dendritic motifs, except after a pre-polymerization phase (polymer 5). The environmental conditions to which the polyesters are subjected after use (compost, urban sewage sludge, soil) also affect the action of microorganisms (polymer 7).

\section{Conclusion}

This work shows that the synthesis method is a parameter allowing or not the biodegradability of polyesters in an elastomeric state. Indeed, such polymers synthesized by enzymatic methods are thus more biodegradable than those synthesized by chemical methods. However, this difference disappears under processing at high temperature often required in industrial applications of a biodegradable polymer, which could drastically decrease its biodegradability.

The choice of the synthesis method depends on the utilisation envisaged for a polyester. Chemical synthesis is rapid and can be applied to a large mass of monomers, or when polymers need to have a slow biodegradation kinetic. Enzymatic synthesis is more expensive, 
suitable for specific products with high added value which do not require processing at high

306 temperature. Enzymatic synthesis can also be used to obtain polymers intended to disappear 307 via biodegradation after use.

\section{Acknowledgements}

This work was supported by ONIDOL (France). We would like to thank Marjorie Sweetko for English language revision and Virgile Calvert for his technical help.

\section{References}

1. Nair LS, Laurencin CT (2007) Prog Polym Sci 32:762-798

2. Weyland M, Daro A, David C (1995) Polym Degrad Stab 48:275-289

3. Jakubowicz I. (2003) Polym Degrad Stab 80:39-43Koutny M, Sancelme M, Dabin C, Pichon N, Delort A-M, Lemaire J (2006) Polym Degrad Stab 91:1496-1503

4. Kawai F, Watanabe M, Shibata M, Yokoyama S, Sudate Y, Hayashi S (2004) Polym Degrad Stab 86: 15-114

5. Muller R (2003). Synthèse du projet européen SMT sur la biodégradabilité des matériaux.

6. Bewa, H (2005) Biodégradabilité et matériaux polymers biodegradables. Note de synthèse ADEME.http://www2.ademe.fr/servlet/getBin ?name=8E9C123D5A10CF6479D7A6AA BEEE91641140709716872.pdf,

7. Avérous, L (2004) J Macromol Sci 44:231-274

8. Gandini A (2011) Green Chem 13:1061-1083 
9. Suriyamongkol P, Weselake R, Narine S, Moloney M, Shah S (2007) Biotechnol Adv 25:148-175

10. Lunt J (1998) Polym Degrad Stab 59:145-152

11. Edlund U, Albertson A-C. (2003) Adv Drug Deliv Rev 55:585-609

12. Wolf O, Crank M, Patel M, Marscheider-Weidermann F, Schleich J, Husing B, Angerer, G (2005) Techno-economic feasibility of large-scale production of bio-based polymers in Europe. Polylactic acid (PLA). European Science and Technology Observatory, EUR 22103 EN pp 50-64

13. Roumanet P-J, Laflèche F, Jarroux N, Raoul Y, Claude S, Guégan Ph (2013) Eur Polym J $49: 813-822$

14. Fradet A, Maréchal E (1982) Adv Polym Sci 43:51-142

15. Fradet A, Tessier M (2003) Polyesters. In: Rogers, M. E., Long, T. E. (eds) Synthetic methods in Step-Growth Polymers, John Wiley \& Sons, Inc: Hoboken, New Jersey, pp $17-132$

16. Jaeger KE, Eggert T (2002) Curr Opin Biotechnol 13:390-397

17. Hasan F, Shah AA, Hameed A (2006) Enzyme Microb Technol 39:235-251

18. Lucas N, Bienaime C, Belloy C (2008) Chemosphere 73:429-442

19. Shah AA, Hasan F, Hameed A, Ahmed S (2008) Biotechnol Adv 26:246-265

20. Da Silva G, Mack M, Contiero J (2009) Biotechnol Adv 27:30-39

21. Yang Y, Lu W, Zhang X, Xie W, Cai M, Gross R (2010) Biomacromolecules 11:259-268

22. Kulshrestha AS, Gao W, Gross R. (2005) Macromolecules 38:3193-3204

23. Yang Y, Lu W, Cai J, Hou Y, Ouyang S, Xie W, Gross AA (2011) Macromolecules 44:1977-1985

24. Zhang Y-R, Spinella S, Xie W, Cai J, Yang Y, Wang Y-Z, Gross R (2013) Eur Polym J 49:793-803 
25. Christensen MW, Andersen L, Husum TL, Kirk O (2003) Euro J Lipid Sci Technol $105: 318-321$

26. Montaudo G, Rizzarelli P (2000) Polym Degrad Stab 70:305-314

27. Massardier-Nageotte V, Pestre C, Cruard-Pradet T, Bayard R (2006) Polym Degrad Stab $91: 620-62$

28. Rabiller C, Maze F (1989) Magn Reson Chem 27:582-584

29. Mazur AW, Hiler GD, Lee SSC, Armstrong MP, Wendel JD (1991) Chem Phys Lipids 60:189-189

30. Spyros A, Phillipidis A, Photis P (2004) J Agric Food Chem 52:157-164

31. Lim L-T, Auras R, Rubino M (2008) Prog Polym Sci 33:820-852

32. Gleadall A, Pan J, Atkinson H (2012) Polym Degrad Stab 97:1616-1620

33. Mochizuki M, Hirami M (1997) Polym Adv Technol 8:203-209

34. Weir N, Buchanan F, Orr J, Dickson G (2004a) Proc Inst Mech Eng H 218:307-319

35. Weir N, Buchanan F, Orr J, Farrar D, Dickson G (2004b) Proc Inst Mech Eng H 218:321-330

36. Sawada H (1998) Polym Degrad Stab 59:365-370

37. Ikada Y, Tsuji H. (2000) Macromol Rapid Commun 21:117-132

38. Rudnik E, Brassioulis D (2011) Ind Crops Prod 33:648-658

39. Widjaja A, Yeh T-H, Ju Y-H (2008) J Chin Inst Chem Engrs 39:413-418

40. Hölter D, Burgath A, Frey H (1997) Acta Polym 48:30-35

41. Umare, S.S., Chandure, A.S., Pandey R.A. (2009) Polym Degrad Stab 92:464-479

42. Gottschalk G. (1979) Bacterial metabolism. Springer Verlag (Ed) New-York Inc, USA, pp 34-78

43. Stanier RY, Ingraham JL, Wheelis ML, Painter PR (1986) The microbial world. In: Prentice-Hall, Englewood Cliffs (ed), $5^{\text {th }}$ edn.New Jersey 07632, pp 183-195 
379 Table 1. Characteristics of the five polyesters synthesized by different methods

380

381 Table 2: Approximate time theoretically required for $1 \mathrm{~g}$ of biomass in a waste treatment

382 plant to mineralize $100 \mathrm{mg}$ of polymer

383

384

385

386

387

388

389

390

391

392

393

394

395 
Figure 1. Principal glyceridic motifs present in the polyesters. Each letter corresponds to an atom of carbon identified by ${ }^{13} \mathrm{C}$ NMR

$\mathrm{R}=$ oleic di-acid, $\mathrm{De}=$ dendritic motif

Figure 2. Extended zone of the ${ }^{13} \mathrm{C}$ NMR spectrum corresponding to the principal glyceridic motifs in a polyester obtained from esterification of glycerol by oleic di-acid

Attributions (cf. Fig. 1): 62.3 ppm L $\mathrm{L}_{1,2} \mathrm{G} ; 63.3$ ppm De B; 63.6 ppm $\mathrm{L}_{1,2} \mathrm{~F} ; 64.5$ ppm T1 I; $66.1 \mathrm{ppm}$

Figure3 : Consumption of $\mathrm{O}_{2}$ and release of $\mathrm{CO}_{2}$ by a biomass from sludge mud placed in contact with vegetal pulp (polymer 6, - — ) and PLA (polymer 7, _ _ ), endogen respiration deduced. Error bars represent the standard error of mean three replicates $(n=3)$

Figure 4. Consumption of $\mathrm{O}_{2}$ and release of $\mathrm{CO}_{2}$ by a biomass from sludge mud placed in 


\begin{tabular}{|c|c|c|c|c|c|}
\hline & \multicolumn{3}{|c|}{$\begin{array}{c}\text { Thermo-chemical } \\
\text { synthesis }\end{array}$} & \multirow[t]{2}{*}{$\begin{array}{l}\text { Enzymatic } \\
\text { synthesis }\end{array}$} & \multirow{2}{*}{$\begin{array}{l}\text { Enzymatic }+ \\
\text { thermo-chemical } \\
\text { synthesis } \\
5\end{array}$} \\
\hline Polymer number & 1 & 2 & 3 & & \\
\hline $\mathrm{T}^{\circ}$ Synthesis $\left({ }^{\circ} \mathrm{C}\right)$ & $65(7 d)$ & 160 (3h) & 160 (8h) & $65(6 d)$ & $65(4 d)$ \\
\hline (time) & \multicolumn{3}{|c|}{180 (1h) } & \multicolumn{2}{|r|}{$160(4 h)$} \\
\hline Catalyst: & & & & Novozyme & Novozyme \\
\hline Physical state & iscous liquid & elastomeric & viscous liquid & elastomeric & elastomeric \\
\hline Mw (g/mole) & 900 & ND* & 31280 & ND* & ND* \\
\hline $\mathrm{Mn}$ (g/mole) & 500 & & 9200 & & \\
\hline \multicolumn{6}{|l|}{ Motif } \\
\hline De (\%) & 8 & 32 & 26 & 18 & 13 \\
\hline $\mathrm{L}_{1,2}(\%)$ & 13 & 14 & 19 & 20 & 21 \\
\hline $\mathrm{L}_{1,3}(\%)$ & 26 & 36 & 40 & 36 & 38 \\
\hline $\mathrm{T}_{1}(\%)$ & 54 & 17 & 15 & 25 & 29 \\
\hline $\mathrm{T}_{2}(\%)$ & 0 & 0 & 0 & 0 & 0 \\
\hline $\begin{array}{l}\text { Regioselectivity of } \\
\text { the primary } \mathrm{OH}(\%)\end{array}$ & 87 & 78 & 83 & 80 & 82 \\
\hline Degree of substitution & 1.5 & 2.1 & 2.1 & 1.9 & 1.8 \\
\hline
\end{tabular}

419 ND* Molecular mass not determined, this polyester being an insoluble cross-linked elastomer De $=$ dendritic motif 


\begin{tabular}{cccc}
\hline & C $\%$ & $\begin{array}{c}\text { In Oxytop System } \\
\text { (month) }\end{array}$ & In an urban sludge plant \\
& & 28.4 & 14.2 \\
Polymer 2 & 68.9 & 5.4 & 2.7 \\
Polymer 3 & 68.0 & 4.8 & 2.4 \\
Polymer 4 & 65.0 & 23.0 & 11.5 \\
Polymer 5 & 67.4 & 1.9 & 0.9 \\
\hline
\end{tabular}

433

434

Table 2

435

436

437

438

439

440

441

442

443 


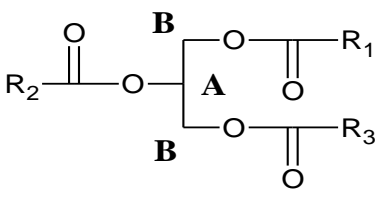

Motif De

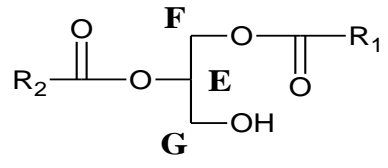

Motif $\mathbf{L}_{\mathbf{1 , 2}}$

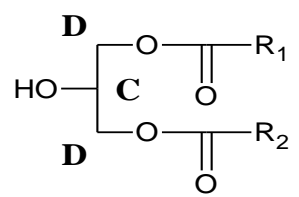

Motif $\mathbf{L}_{\mathbf{1 , 3}}$

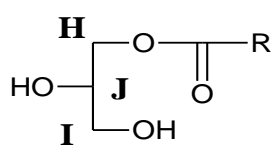

Motif $\mathbf{T}_{\mathbf{1}}$

Figure 1 


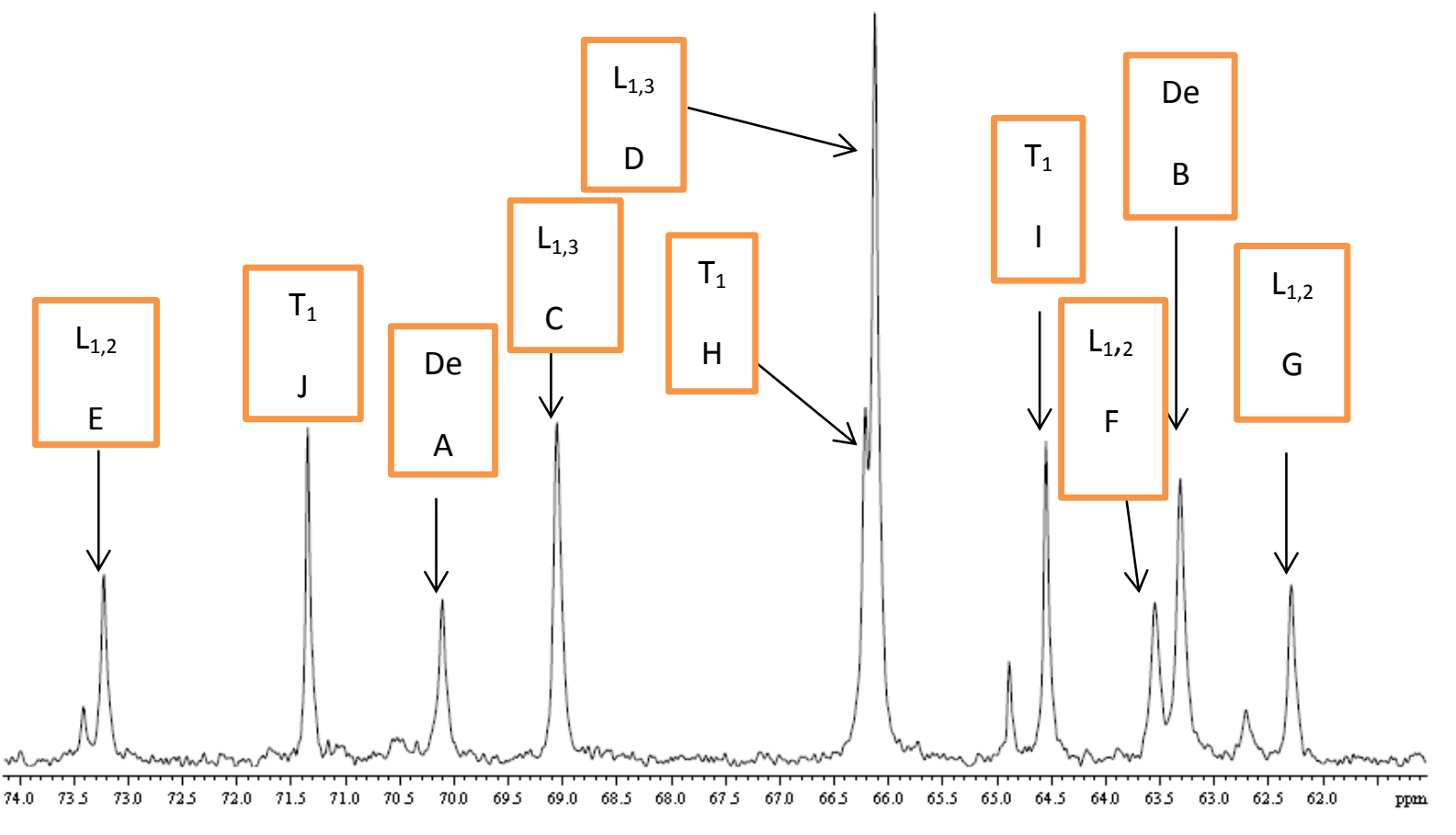

$449 \quad$ Figure 2

450

451

452

453

454

455 


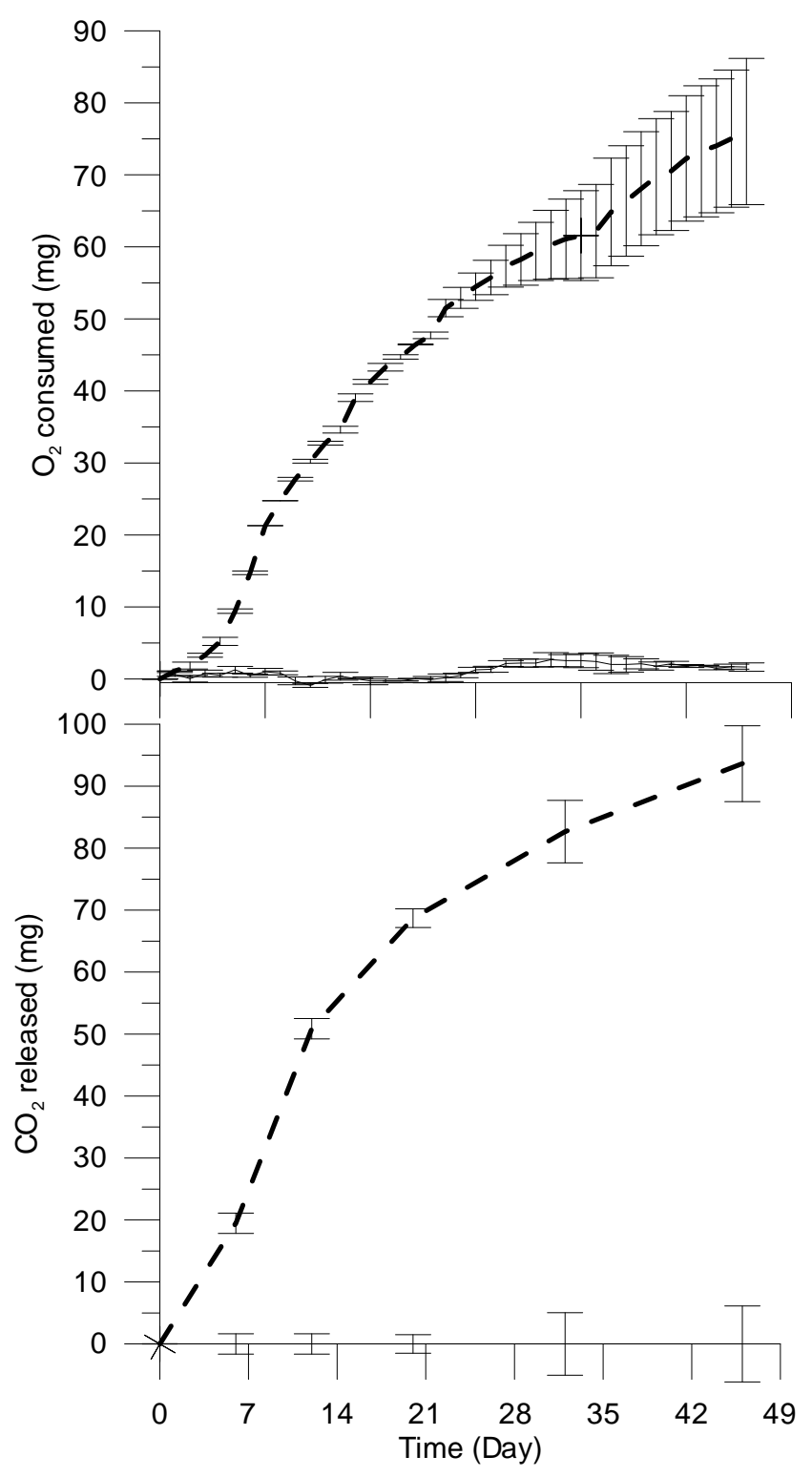

456

457

Figure 3

458

459 


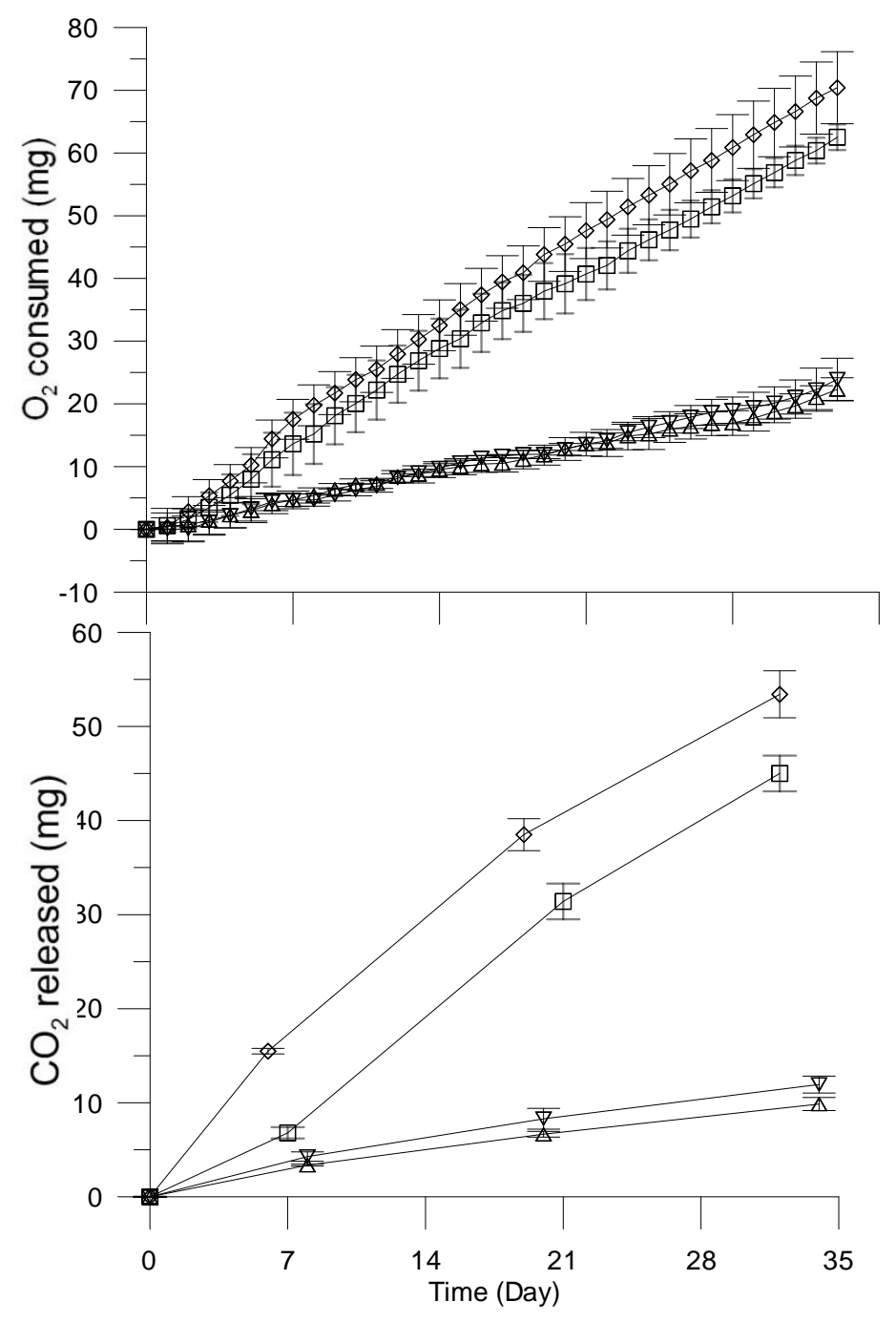

460

$461 \quad$ Figure 4

462

463 